\title{
Images of grandparents in English South African children's picture books
}

\author{
S.I.I. Olën, ${ }^{\star}$ M.P. Machet \& M. Marchand \\ Children's Literature Research Unit, University of South Africa, P.O. Box 392, Pretoria, 0003 Republic of South Africa \\ olensii@unisa.alpha.ac.za
}

\begin{abstract}
This article is a qualitative analysis of intergenerational relationships as reflected in 25 English South African children's picture books. It is hypothesised that children's books are a mirror of society's attitudes, values, norms and perceptions. Therefore an analysis of picture books should reveal current attitudes towards grandparents and elderly people and also reflect the similarities and differences in the various South African cultures pertaining to these issues. Issues that will be examined are images of grandparents, the role of grandparents, relationship between grandparents and child and activities shared by children and grandparents.
\end{abstract}

Die artikel is 'n kwalitatiewe ontleding van verhoudings tussen verskillende geslagte soos dit uitgebeeld word in 25 Engelstalige Suid-Afrikaanse kinderprenteboeke. Daar word van die hipotese uitgegaan dat kinderboeke 'n spieëlbeeld van 'n gemeenskap se ingesteldheid, waardes, normes en persepsies is. 'n Ontleding van prenteboeke behoort dus ' $n$ indruk te gee van die hedendaagse ingesteldheid teenoor grootouers en bejaardes en dit behoort ook die ooreenkomste en verskille in die verskillende Suid-Afrikaanse kultuurgroepe te reflekteer. Aspekte wat ondersoek word, is die uitbeelding van grootouers, die rol wat grootouers speel, die verhouding van grootouers met die kind en die aktiwiteite wat grootouers en kinders saamdoen.

*Author to whom correspondence should be addressed.

This research project has as its hypothesis that children's literature reflects social attitudes, values, norms and perceptions (Albrecht 1953; Schucking 1966). Children's books should therefore be a mirror of the current attitudes on different issues and would also reflect the similarities and differences in different cultures pertaining to these issues. Although the researchers do not wish to be prescriptive, the insights gained from this study of children's books could indicate ways in which societal attitudes and perceptions might need to change. Such indications might be helpful to authors and publishers.

A study of South African children's literature which deals with intergenerational relationships in the family today should therefore shed light on these relationships. It should also indicate the current prevailing perceptions of the elderly and grandparents in the different cultures represented in South Africa which has often been referred to as 'a rainbow nation'.

\section{Intergenerational relations}

Intergenerational relations in the family can be described as a set of interlocking, vertical ties, which weave together interdependent relationships and interconnected lives. If represented linearly the grandparents are at one end and the grandchildren at the other. Parents form a generational bridge between grandparents and grandchildren (Hagestad 1984:105). The generational relationship is an embodiment of the transmission of material and immaterial values (Garms-Homolová, Hoerning \& Schaeffer 1984a:1). The study of the family represents a multifaceted and diverse area of scientific involvement with the subject of intergenerational relationships. In this context the term generation describes lineage and succession, whereby purely biological determinants such as family relationships play a greater or lesser role depending on the particular cultural and sociohistorical conditions (Garms-Homolová, Hoerning \& Schaeffer1984a:6).

South Africa is a multicultural country and one would expect to find these different cultural norms reflected in children's books. According to Møller (1994:158) the 1990/1 baseline study of South Africa's elderly over 60 years of age, found that $56 \%$ of urban black elders live in three-generational households with their children and grandchildren. In these urban households it was also found that the head of the household is most often a grandparent (1994:165). Studies show that if grandparents own the home they have a position of authority and play an important role in transmitting social values to children (Garms-Homolová, Hoerning \& Schaeffer 1984b:15). Economic interests often dictate multigenerational family units sharing the same home. This is more common among agrarian societies and this form of family tends to disappear with urbanisation. The modern Western family is characterised by the need for distance and personal fulfilment and greater emphasis is placed on individuality (Garms-Homolová, Hoerning \& Schaeffer 1984c:59-61). In the traditional system of intergenerational relations children have been an element of continuity. Today in 
Western societies the child is regarded as an individual person whose growing up, nurturing and education is considered a special task. Western families are very childcentred with the child the 'unquestioned sovereign in the family' (Rosenmayr 1984:83).

A study of intergenerational relationships in the USA indicated that children feel very lucky to have grandparents who they perceive as 'very important people' (Kornhaber \& Woodward 1981:6-39). Children receive unconditional love from grandparents uncomplicated by demands and expectations. Children who have this type of relationship are able to extend these positive feelings to older people in general. Unfortunately, relatively few children have the opportunity of developing this relationship with their grandparents, books can therefore play an important role in helping children develop a respect for old people.

\section{Roles of grandparents}

Grandparents may have multiple roles. Kornhaber and Woodward (1981:167) suggest that these roles transcend social changes because they are based on biological and psychological realities. Grandparents help create family continuity. They achieve this partially by being the family historian who connects the child with the past and gives the grandchild access to 'other voices'. In this role grandparents also transmit ethnic heritage, religious faith and values (Garms-Homolová, Hoerning \& Scaeffer 1984:1; Kornhaber \& Woodward 1981: 167-170). Other important roles are those of mentor, role model, and an imaginative counterpoint to the purposeful world of parents and teachers (Kornhaber \& Woodward 1981:170-174).

\section{Methodology}

Twenty-five picture books published by Southern African authors in English which have a grandparent or grandparents as a protagonist(s) were studied. The criteria for selection were that the books were published during the period 1987 to 1997 to ensure that they reflect current attitudes; that they would still be available in bookshops or libraries; and they would be suitable for reading with or by children between the ages of four and eight. Twenty-three of the books were first published in Southern Africa although some of them, such as Daly (1996), have subsequently also been published abroad. The book by Bouma (1987) was published in London in 1987 and no record can be found of it being published in South Africa prior to this. However, it was decided to include it as Paddy Bouma is a South African author who has had several books published in this country. Although The day Gogo went to vote (Sisulu 1997) was first published in the USA in 1996, this work was included as the author resides in Cape Town and the book has a South African theme with a South African family. Strictly speaking the work by Greathead (1996) is not a picture book although it has several illustrations, but it has been included because if read aloud the book would be suitable for seven- to eight-year-old children and also because the grandfather in this story plays a central role.

English is spoken as a first language by $8.7 \%$ of South Africans (South African Institute of Race Relations 1993: 256), but it is increasingly the lingua franca in South Africa (Young 1987:4). English language books are therefore also read by South Africans whose mother tongue is not English. The books which have been selected for analysis represent all South African ethnic groups except for the Asians. Although this group comprises a small percentage of the country's population $(2.6 \%)$, it is interesting that the researchers could not find any books representing this ethnic group (South African Institute of Race Relations 1993:254).

The methodology followed was to read the text and examine the illustrations in each book and to evaluate the image and role of the grandparent(s) portrayed. The evaluations were done by a minimum of two people to ensure consistency. A content analysis coding form developed by Balkwell, Ritblatt, Semlak and Deutsch (1995) was used as a guideline. The purpose of the coding form is to assess the physical appearance, roles and activities of the elderly in books. The proximity of the grandparent to the child was also noted. Activities carried out by grandparents in the company of their grandchildren were identified and the intergenerational relationships were explored. As it is hypothesised that the literature is a reflection of society's attitudes and perceptions, any similarities and differences in the cultures depicted in the books analysed have been pointed out.

\section{Images of grandparents}

Without exception the images of the elderly in all the books studied were positive to very positive (see Figure 1).

While some of the grandparents were more aged than others and walked slowly or were not able to stand for long periods (Daly 1996; Naidoo 1996; Sisulu 1997), none are depicted as stooped, obese (except for the grandmother in Not so fast, Songololo), sickly or with major handicaps such as being confined to wheelchairs or bedridden. Most of the older African women are portrayed wearing scarves tied around their heads and so even if they were greyhaired this fact would be concealed. Even when the text specifically states that these elderly people are greyhaired and wrinkled they are generally active enough to walk, cook and do handicrafts.

Grandparents are generally shown as competent people; many still play an active role in life and help their grandchildren acquire necessary competencies. In My granny can read and write (1996), the granny is shown learning to read and write because these are skills that are required in today's society. This helps her grandson, who is negative about school, to change his mind and become more positive about going to school. The grandfather in Busisiwe's bicycle (Randall 1993) helps Busisiwe set up her garden and makes wire models of bicycles which are sold in town 


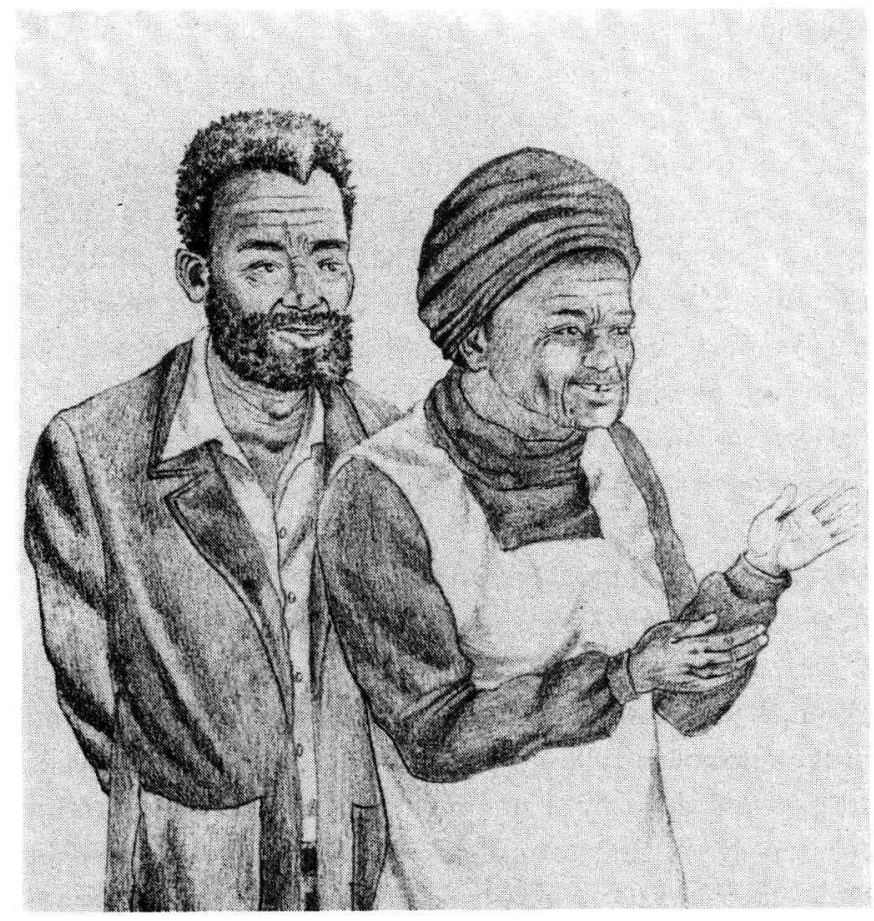

Figure 1 Busisiwe's grandparents (Randall 1993:22). Reproduced with kind permission of MacMillan Boleswa.

to help Busisiwe get enough money to buy her bicycle. The granny in Chloe's Granny (Holloway 1995) is also competent and independent, showing Chloe how to paint eggs and rock and roll.

In those works depicting black African culture the protagonists never make fun of the grandparent or condescend to him or her. The tone of the text and illustrations is respectful. Notable examples of such works are My granny can read and write (Naidoo 1996) and The day Gogo went to vote (Sisulu 1997). Although the grandmothers in both these books are very elderly and walk slowly, they both have great dignity. Gogo is determined to vote even if it kills her - she is not going to let an opportunity for which she has waited her entire life go by despite her advanced age.

'Mother and Father asked my uncles and aunts to help them to tell Gogo she could not go to vote. But Gogo refused to listen.

"You want me to die not having voted?" she asked' (Sisulu 1997:16).

The grandmother in My granny can read and write (Naidoo 1996) is illiterate and quietly sets about mastering reading and writing at great personal sacrifice and despite the fact that she is 75 years old.

The South African books written from a Westernised standpoint do, however, sometimes make fun of the grandparent. This is the case with Flight from Hout Bay (Savage 1991) and Where are Grandpa's glasses? (Constable 1994) (although the latter depicts black characters it has been written by white South Africans).

It is interesting to note that some of the books by white South Africans portray more explicitly individualistic grandparents which reflects the trend in Western society of personal fulfilment and individuality (Garms-Homolová, Hoerning \& Schaeffer 1984c:59-61). In The red button (Martin 1994) Terence likes to ask questions and so he visits his Grandfather because

'Grandad Moses never got tired of answering questions. He ENJOYED questions. If he could not find the answer in one of the thousands of books in his bookcases, or in the books which lay in big piles all over the floor, he took Terence to the museum' (Martin 1994:5).

Chloe's Granny in the book of the same name is obviously independent and not daunted by her age (Holloway 1995). She wears jeans with green tackies, teaches Chloe to dance rock and roll, fixes old furniture, sails down the Nile and rides on a camel (Holloway 1995:13, 21, 25, 29, 30) (see Figure 2).

\section{Role of grandparents}

The role of grandparents in black African societies is frequently that of a surrogate parent. Very often the father or mother or both have to work in cities and are only able to return to their homes at weekends or even less frequently (Wilson \& Ramphele 1989:175). Young children are left in the care of their grandparents or, in many cases, in the care of one grandparent, who then fulfil the surrogate parent role. My granny can read and write (Naidoo 1996), Desert

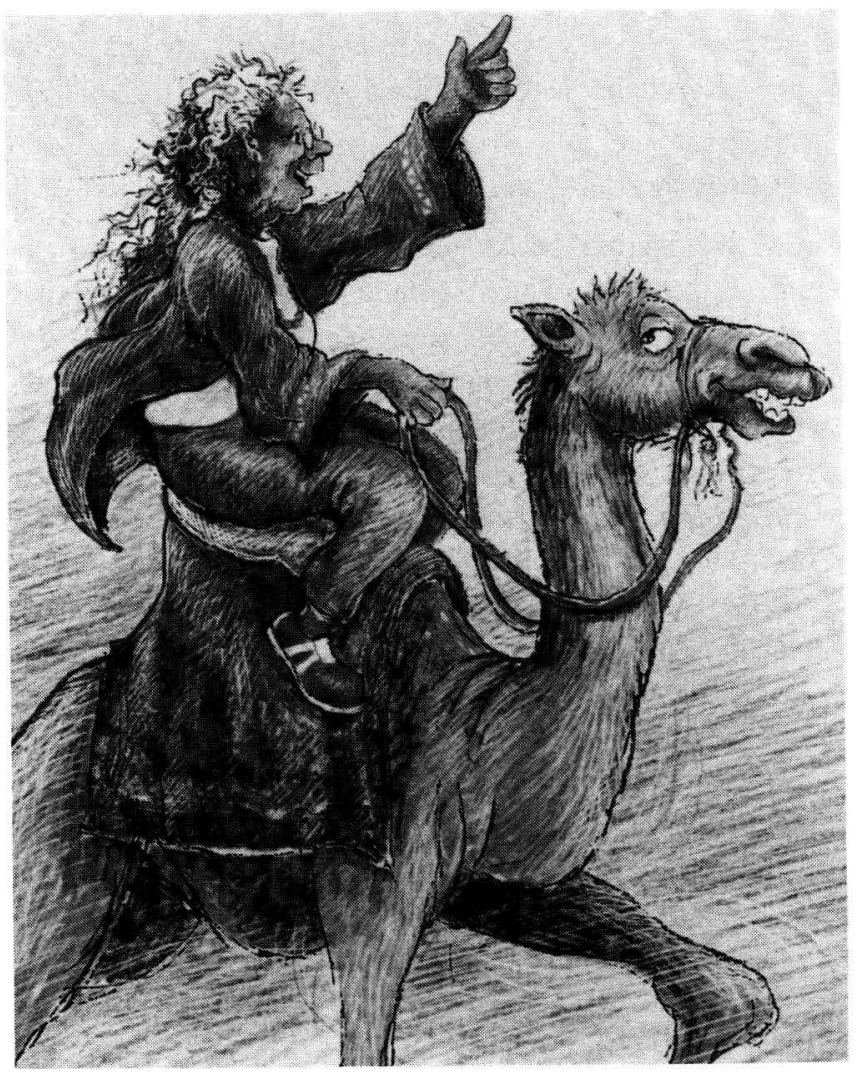

Figure 2 Chloe's granny riding the camel (Holloway 1995: 30). Reproduced with kind permission of Human \& Rousseau and Marjorie van Heerden. 
December (Haarhoff 1991), The dove (Stewart 1994), Busisiwe's bicycle (Randall 1993), Papiniki (Quail 1988) and Thami and Thandi (Greathead 1996) all portray grandparents acting as surrogate parents.

One would not expect to find this role in Westernised cultures where less importance is attached to the extended family and grandparents seldom stay with their children and grandchildren. In these societies it is becoming more common for the elderly to live independent lives until they reach a certain age or their health starts failing and then they move to retirement villages or homes for senior citizens (Garms-Homolová, Hoerning \& Schaeffer 1984:61; Mutran \& Reitzes 1984). It is more usual for the grandparent in a Western society to play a support or mentoring role than the role of surrogate parent. Again this role is reflected in the children's literature by white South African writers. For example, in The red button (Martin 1994) Grandfather Moses answers questions that other people are too busy to answer. In Barney climbs a mountain (Mennen 1987) Granny is coming to visit and she is going to sleep in Barney's bed. Barney is very upset about giving up his bed, but Granny helps him to come to terms with it.

Grandparents in more Western stories also participate in the children's fantasies which is consistent with roles of grandparents in Western societies identified by Kornhaber and Woodward (1981:170-174). For example in Our secret (Heese 1993) the grandmother and grandson share a secret that 'one day we are going to walk on the moon' (Heese 1993:9), and 'fly piggy-back through the sky' (Heese 1993: 10). In Bertie visits Granny (Bouma 1987) Granny treats Bertie, the stuffed hippo as if he is alive. In Goodnight, Grandpa the grandfather collects stars with the grandson and tells him 'Grandpa will put the sparkle of a tiny stars in each of your eyes and they will always shine brightly, just like the stars in the night sky' (Van Heerden 1990:20). In Barnie climbs a mountain (Mennen 1987) the granny and parents persuade Barney to give up his bed for Granny and sleep on the couch by pretending it is a cave.

Fantasy in the African story Vusirala the giant (Matross 1995) takes the form of a traditional folk tale. In this story a giant terrorises the people in a small village but is outwitted by a little girl. The grandfather plays a peripheral role only. In Charlie's house (Schermbrucker 1989) Charlie fantasises about having a wonderful house, unlike the reality in Guguletu where he lives with his granny and mother in a shack of corrugated iron and cardboard. However, in general fantasy is not present in the African stories examined, which focus more on reality and often deal with innovative ways to make money to improve the quality of their lives. An example of this is Papiniki (Quail 1988). In this book Papiniki asks the granny to make large pots that they can sell so that they can buy a cart. Once they have a cart he will be able to fetch more water and grow vegetables which they will be able to sell.

The grandparent also has a role to play as a problemsolver or information provider. In The red button (Martin

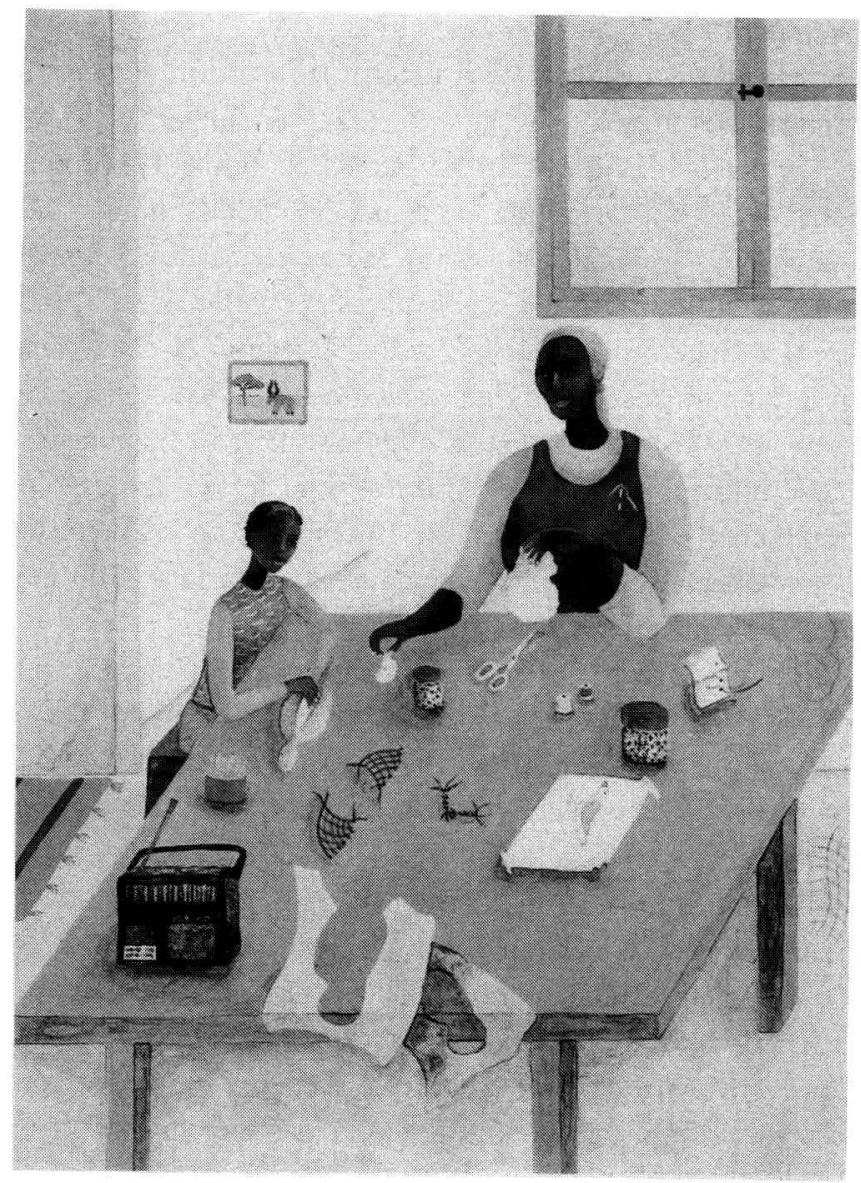

Figure 3 Lindi's grandmother showing her how to make the dove (Stewart 1994:21). Reproduced with kind permission of David Philip and Jude Daly.

1994) Grandad Moses is prepared to answer questions and in Flight from Hout Bay (Savage 1991) Oupa is able to tell the boys what to do about the injured bird.

Sometimes the role of the grandparent is to pass on skills to the grandchild. The grandmother in The dove (Stewart 1994) shows Lindi how to cut the material for the dove and how to stitch it (see Figure 3).

The grandfather in Thami and Thandi (Greathead 1996) shows his grandson how to clean and bandage the wound on the donkey's leg and the grandfather in Kensami's kite (Deall 1995) shows the child how to fashion a kite correctly. In Busisiwe's bicycle (Randall 1993) the grandfather shows Busisiwe how to plant seeds and care for her own garden.

Some of the stories are used to transmit cultural values. In Busisiwe's bicycle (Randall 1993) Busisiwe gives her hard earned money which she is saving to buy a bicycle to her grandmother to pay for a doctor and medicine for her baby brother who is ill. The strong value of communal good, characteristic of African society, is emphasised (Wilson \& Ramphele 1989). This contrasts with Chloe's grandmother (Holloway 1995) where the value of individuality is emphasised. This is done by showing the various unusual activities of Chloe's grandmother as compared to the conventional activities of the other grandmothers. In 
Grandfather's hat (Barnard 1992) the importance of obedience and respect for elders in African society is emphasised. Joe is angry with his grandfather who has reprimanded him for throwing stones at birds. His grandfather does not give him a chance to defend himself although he was actually throwing stones at the tree to knock down seed pods. He decides to throw grandfather's hat into the tree where it becomes stuck. Because he has done something disrespectful he cannot ask for assistance. He knows he must get the hat as otherwise he will be punished '... he must get the hat. He did not want to feel the pain of grandfather's stick' (Barnard 1992:6). Corporal punishment, especially from a grandparent, did not feature in any of the books depicting white families.

An important role for a grandparent in the family, but which is conspicuous for its absence in most of the books analysed for this project, is the role of custodian of much of the family's early history and memories. There is only one example of this in the books which the researchers analysed: Grandma's hat (Khan 1989). In this book the grandmother tells of an incident when she lost her hat when she was a child. The details of her life in the Karoo are also included as well as explanations of how life has changed. However, apart from this example none of the stories are used to transmit the cultural heritage in the form of a story. One often hears adults express the wish that they had taken the trouble to learn more about their family history from their grandparents while they were still alive. Authors should be encouraged to show grandparents as more proactive in this role by relating family stories and histories, even if it is while they are involved in other activities such as walking or baking. Perhaps grandparents could also be shown to be recording these stories either on tape or in writing.

\section{Proximity of grandparents to child}

In almost all the books about black Africans the grandparents live in the same house as the grandchild, even when the parents are present and the grandparent has not assumed the role of surrogate parent, for example Charlie's house (Schermbrucker 1989) and The day Gogo went to vote (Sisulu 1997). There are only a few books where it is clear that the grandparent does not live in the same house, for example Not so fast, Songololo (Daly 1996), but obviously the grandparent is still living close by in the same neighbourhood. In Thobile and the tortoises (Pinnock 1992) we are told that Thobile and his grandmother both live in London, but although they may be part of the same household, this information is not given as it has no relevance to the story.

Again the difference between the books depicting black South African and the more Westernised perspective is apparent. In the more Westernised books depicting white families the proximity of the grandparent to the child is seldom explicitly stated. This reflects the trend in Western countries, such as the USA, for grandparents to live separately from their children (Kornhaber \& Woodward 1981:6-39). An exception is The red button where we are told that Grandfather Moses lived at the end of the road (Martin 1994:2). Usually all that can be deduced is that the grandparent is not part of the household. Grandma's hat could be an exception as it appears that Grandma stays with the family (Khan 1989:2) but this is not clearly indicated.

In Goodnight, Grandpa (Van Heerden 1990) the grandfather has died and the book is about dealing with death. However, the closeness of Marcus' relationship to his grandfather is indicated in the fantasy when he dreams of collecting stars with his dead grandfather.

The close relationship between grandparent and child in African culture is clearly depicted in several of the books. This corresponds to Møller's (1994:186) finding that even in the present time 'filial piety, obedience and respect for the opinions of elders appear to be strong values among the youth in most three generation families'. Several illustrations in Not so fast, Songololo (Daly 1996), The dove (Stewart 1994) Busisiwe's bicycle (Randall 1993) and The day Gogo went to vote (Sisulu 1997) show the grandmother having physical contact with the grandchild, for example holding hands and the grandparent with an arm around the child (see Figure 4).

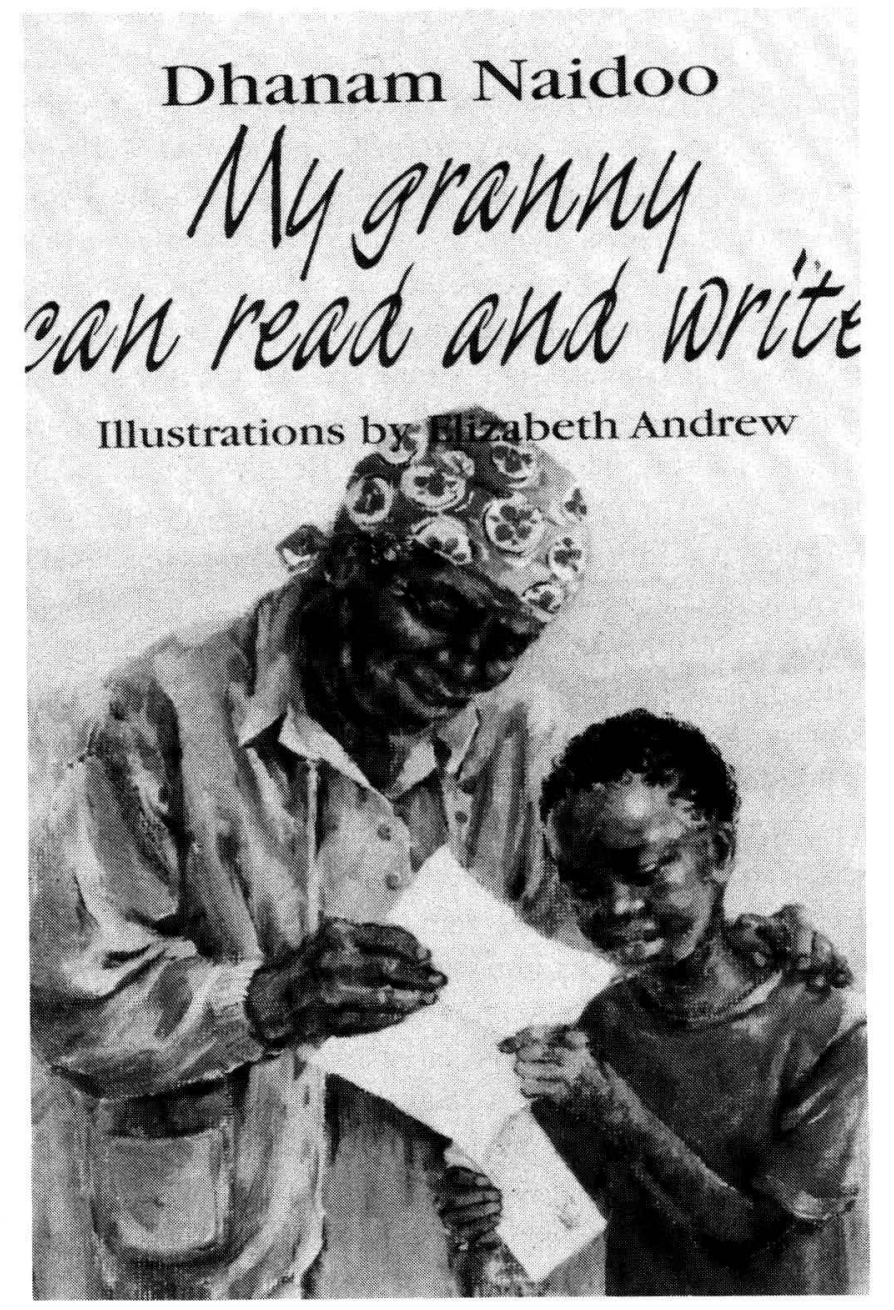

Figure 4 Granny with arm around Bongani while they read the letter she wrote herself (Naidoo 1996:cover). Reproduced with kind permission of Human \& Rousseau and Elizabeth Andrew. 


\section{Activities shared by children and grandparents}

The characters in the books depicting black Africans which were analysed are chiefly occupied with survival activities: working on the land, walking miles to go to literacy classes or making beadwork to sell to stave off starvation. There is little or no time in these stories for watching TV, going on excursions to places like museums or for reading books. An exception is the grandfather who sits down to read his grandchildren a story once he has found his glasses in Where are Grandpa's glasses? (Constable 1994), but this book has been written by white South Africans and the book is published by the READ organisation which wants to stress the importance of reading.

Unlike people in Western countries who walk or jog for exercise, the old and young in developing countries will be seen walking together for miles to get somewhere - to go to town, to do shopping, to visit family. When distances are too great for walking the bus is often used for travel. However, unlike rural blacks, the more sophisticated urban blacks are regularly portrayed as travelling by air and by motorcar. These different activities are reflected in the books analysed: several of the books make mention of bus rides. In Desert December (Haarhoff 1991), a modern version of the Christmas story set in South Africa, the young boy sets out in donkey cart to find his mother. However, in Thobile and the tortoises (Pinnock 1992), Mama Vulu, Thobile's grandmother, and Thobile fly to South Africa from London and then they take a taxi.

As has previously been mentioned the grandparents share a variety of activities with the children. The grandmother in Not so fast, Songololo (Daly 1996) goes shopping with her grandson. In The dove (Stewart 1994) Lindi and her grandmother walk a long distance to try and find buyers for her grandmother's beadwork. In Thami and Thandi Grandfather accompanies Thami to Mr Minty's shop to see about finding a bridle and harness for Thandi, he also walks with Thami to fetch the cart and goes with Thami and Shadrack to the police station to make a report (Greathead 1996:17, 26, 34). In Papiniki (Quail 1988) Papiniki helps his grandmother make large clay pots.

Many of the grandparents are very active in creating or making things. In Thami and Thandi Grandfather finds pieces of leather to make a saddle for Thandi and alters the harness to fit the donkey (Greathead 1996:16, 23) and when Thandi is injured by a stone thrown by one of the bigger schoolboys he heated 'water on the primus stove and carefully bathed the leg' (Greathead 1996:46). He helps Thami to tie a bandage round the leg to hold the skin in place. This grandfather also cooks food for his grandson (Greathead 1996:9).

In Busisiwe's bicycle (Randall 1993) the grandfather makes wire model bicycles. He also plants and tends a vegetable garden and teaches Busisiwe how to hoe and tend a vegetable garden.

The grandfather in Kensami's kite (Deall 1995) makes carvings of birds and helps a child to make a proper kite which can soar like an eagle. In Grandmother makes a cake (Leggatt 1991) the grandmother mixes, bakes and ices a cake. She allows her grandson to assist as all the other family members are too busy to take care of him. Her grandson also helps to eat the cake!

In Papa Lucky's shadow Papa Lucky teaches his granddaughter to tap dance so well that she can accompany him. 'His feet jived and bamboozled. But I didn't miss a trick. That's what its like being Papa Lucky's shadow' (Daly 1992:2-23).

In My granny can read and write (Naidoo 1996) the grandmother encourages her grandchild to go to school to learn to read and write. Unbeknown to the child for several months his Granny walks long distances to attend literacy classes given by the grandchild's teacher. When he discovers that his Granny has learnt to read and write he is thrilled at his Granny's achievement.

The first time that black people were allowed to vote in South Africa was in April 1994 when democratic elections were held. Gogo is very old and weak, but she is determined to cast her vote despite her poor health, because she would not like to die without having made use of this first opportunity (Sisulu 1997). Her granddaughter accompanies her to the polling station and the next day an item appears in the newspaper.

'The next day there was a picture of Gogo and me in the newspaper. My cousins read aloud the words above the picture: "The past and the future: hundred-year-old voter Mrs. M. Mokoena accompanied by six-year-old greatgranddaughter, Thembi." We felt very proud and important!' (Sisulu 1997:30).

Lindi and her grandmother cannot plant crops because of the floods and need money. Granny makes beads to sell in Durban. On their way to the city they see a dove and back at home Granny helps Lindi to make a stuffed dove from pieces of material and beads. When Granny is unable to sell the beads and keyrings she finds a buyer for the dove and is given more orders (Stewart 1994:26).

In a few of the books it is the child who has the more predominant role with regard to activities. For example in Busisiwe's bicycle (Randall 1993) it is Busisiwe who has the initiative to start a vegetable garden like her grandfather's so that she can make money to buy a bicycle. In the Special fig tree (Andrew 1988) Kate, the granddaughter, collects and sells figs to buy a chair for her grandfather. In Papiniki (Quail 1988) it is Papiniki's idea that his grandmother should make clay pots to sell so that they can buy a cort. A cart will enable him to fetch more water so that he can grow vegetables which they will be able to sell.

The grandparents in the black African stories examined in this study encourage any entrepreneurial activity that the children undertake, often contributing ideas to help the children make money. This money is usually used for survival activities rather than to buy a toy or for fun activities. In Busisiwe's bicycle (Randall 1993) grandfather 
helps Busisiwe to start a vegetable garden so that she can sell her crops for money to buy a bicycle. In Thami and Thandi Thandi pays for a harness for his donkey by gathering a load of firewood (Greathead 1996:18). His grandfather ensures that he fulfils his obligation and gathers and delivers the wood.

The stories of white families are more concerned with activities to pass the time, as with the grandfather who answers Terence's questions and takes him to the museum in The red button (Martin 1994); the grandmother who tells a story about her hat in Grandma's hat (Khan 1989) and the grandmother who gives her grandson sweets from her shop in Bertie visits Granny (Bouma 1987). This reflects one of the roles regarded as important by children in the study by Kornhaber and Woodward (1981). In Grandma's hat (Khan 1989) the family has a car to travel in when they go visiting - they do not use a bus, taxi or donkey cart.

There are two stories about Cape Malays (predominantly Afrikaans-speaking people of Muslim faith descended from slaves or political exiles sent to the Cape in the 17th and 18th centuries from countries in the East such as Indonesia, Malaysia and Ceylon): the Special fig tree (Andrew 1988) and Papa Lucky's shadow (Daly 1991). In these books it is the subtext and illustrations that include distinguishing features of the Cape Malay culture. In Special fig tree (Andrews 1988) it is conveyed through the illustrations of the Cape Dutch houses and the pictures of the people. In Papa Lucky's shadow (Daly 1991) the tap

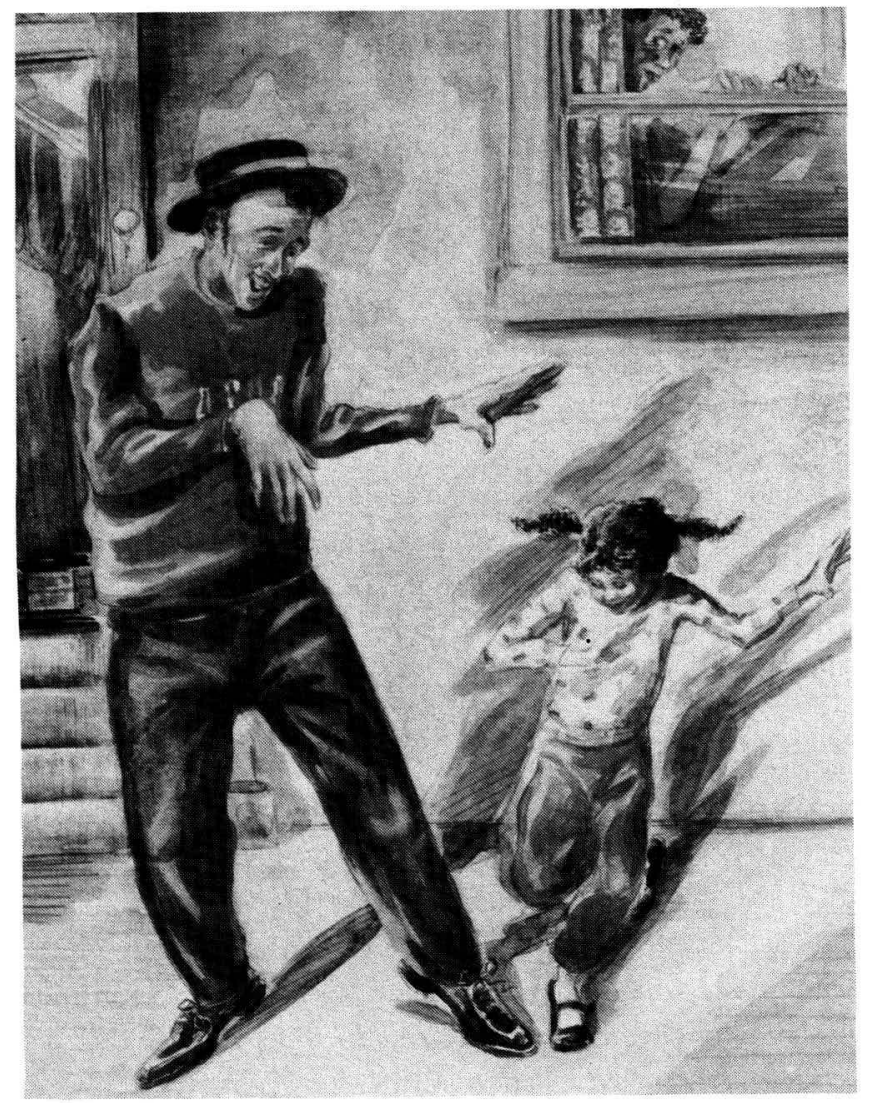

Figure 5 Papa Lucky dancing with his granddaughter (Daly 1992:21). Reproduced with kind permission of David Philip and Nicki Daly. dancing itself, which is very popular with the Cape Malays, conveys the vibrant culture (see Figure 5).

The stories themselves have elements of both black and white South African cultures. The grandfather lives with the family in both stories, as in the black African families. In Papa Lucky's shadow (Daly 1991) the dancing is used to make money which is then used to purchase a fancy iron for the mother, that is a practical gift. In Special fig tree (Andrew 1988) the little girl makes money by selling figs which she then uses to buy a chair for her grandfather. The stories are both realistic and concerned with making money to improve the quality of life.

\section{Conclusion}

It is characteristic of children's literature that it should contain much that is positive even when dealing with realistic situations. It was illuminating to find that many of the books conveyed a warmth of feeling in the intergenerational relationships, particularly in the books where the grandparent acted as a surrogate parent. Intergenerational studies of Westernised societies indicate that it is no longer common for the grandparents to be living in the same household with the grandchildren. There should therefore be more attention given to stories where the grandparents are not only there to provide some fun or entertainment, but visit the grandchildren and emerge as a source of oral history and family memories and as role models worthy of respect.

\section{Note}

1. As the pages are not numbered in most picture books, the researchers have counted the pages starting with the title page to provide page references.

\section{References}

Albrecht, M.C. 1953. the relationship of literature and society. American journal of sociology, 59(5):425-436.

Andrew, E. 1988. Special fig tree. Cape Town: Human \& Rousseau.

Barnard, P. 1992. Grandfather's hat. Manzini, Swaziland: Macmillan Boleswa.

Balkwell, C. et al. 1995. Images of grandparents presented in children's literature: multicultural comparisons of intergenerational family relations. San Diego, CA.: Department of Child and Family Development, San Diego State University.

Bouma, P. 1987. Bertie visits Granny. London: Bodley Head.

Constable, P. et al. 1994. Where are Grandpa's glasses? Illustrated by L. Head. Braamfontein: READ.

Daly, N. 1992. Papa Lucky's shadow. Illustrated by N.Daly. Cape Town: David Philip.

Daly, N. 1996. Not so fast, Songololo. Illustrated by N. Daly. New York: Aladdin Paperbacks. (First published in SA in 1985.)

Deall, A. 1995. Kensani's kite. Johannesburg: Mike Jacklin/ Knowledge Unlimited. 
Garms-Homolová, V., Hoerning, E.M. \& Schaeffer, D. 1984a. Intergenerational relationships: approaches in theory and research, in Intergenerational relationships, edited by V. GarmsHomolová, E.M. Hoerning \& D. Schaeffer. Lewiston, NY: Hofgrefe: $1-10$.

Garms-Homolová, V., Hoerning, E.M. \& Schaeffer, D. 1984b. Intergenerational relationships in the process of civilization, in Intergenerational relationships, edited by V. GarmsHomolová, E.M. Hoerning \& D. Schaeffer. Lewiston, NY: Hofgrefe: 11-16.

Garms-Homolová, V., Hoerning, E.M. \& Schaeffer, D. 1984c. Concepts of solidarity, in Intergenerational relationships, edited by V. Garms-Homolová, E.M. Hoerning \& D. Schaeffer. Lewiston, NY: Hofgrefe:59-62.

Greathead, F. 1996. Thami and Thandi. Illustrated by E. Andrew. Cape Town: Tafelberg.

Haarhoff, D. 1991. Desert December. Illustrated by L. Vermeulen. Cape Town: David Philip.

Hagestad, G.O. 1984. Multigenerational families: socialization, support and strain, in Intergenerational relationships, edited by V. Garms-Homolová, E.M.Hoerning, \& D. Schaeffer. Lewiston, NY: Hofgrefe:105-114.

Heese, M. 1993. Our secret. Illustrated by C. Coetzee. Cape Town: Anansi.

Holloway, M. 1995. Chloe's granny. Illustrated by M. van Heerden. Cape Town: Human \& Rousseau.

Khan, R. 1989. Grandma's hat. Illustrated by T. Milne. Cape Town: David Philip.

Kornhaber, A. \& Woodward, K.L. 1981. Grandparents/grandchildren: the vital connection. Garden City, NY: Anchor Press.

Leggatt, G. 1991. Grandmother makes a cake. Manzini, Swaziland: Macmillan Boleswa.

Martin, J. 1994. The red button. Illustrated by L. Martin. Sandton: Mike Jacklin/Knowledge Unlimited.

Matross, V. et al. 1995. Vusirala the giant. Illustrated by F. Mouton. Cambridge University Press.

Mennen, I. 1987. Barney climbs a mountain. Illustrated by M. Todd. Cape Town: Human \& Rousseau.

Møller, V. 1994. Intergenerational relations in a society in transition: a South African case study. Ageing and society, 14:155-189.
Mutran, E. \& Reitzes, D. 1984. Intergenerational support activities and well-being among the elderly: a convergance of exchange and symbolic interaction perspectives. American sociological review, 49:117-130.

Naidoo, D. 1996. My granny can read and write. Illustrated by E. Andrew. Cape Town: Human \& Rousseau.

Pinnock, P.S. 1992. Thobile and the tortoises. Illustrated by L. Stonestreet. Grahamstown: African Sun Press.

Quail, E. 1988. Papiniki. Illustrated by A. Berry. Johannesburg: Ravan.

Randall, I. 1993. Busisiwe's bicycle. Illustrated by Z. Sothoane. Manzini,Swaziland: Macmillan Boleswa.

Rosenmayr, H. 1984. Norms and solidarity, in Intergenerational relationships, edited by V. Garms-Homolová, E.M. Hoerning \& D. Schaeffer. Lewiston, NY: Hofgrefe:81-89.

Savage, D. 1991. Flight from Hout Bay. Illustrated by L. Charnock. Johannesburg: Varia Books.

Schermbrucker, R. 1989. Charlie's house. Illustrated by N. Daly. Cape Town: David Philip.

Schucking, L.L. 1966. The sociology of literary taste. London: Routledge \& Kegan Paul.

Sisulu, E.B. 1997. The day Gogo went to vote. Illustrated by S. Wilson. Cape Town: Tafelberg.

South African Institute of Race Relations. 1993. Race relations slirvey 1992/93. Johannesburg: The Institute.

Stewart, D. 1994. The dove. Illustrated by J. Daly. Cape Town: David Philip.

Van Heerden, M. 1990. Goodnight Grandpa. Cape Town: Human \& Rousseau.

Wilson, F. \& Ramphele, M. 1989. Uprooting poverty: the South African challenge. Cape Town: David Philip.

Young, D. 1987. Belated concern: language planning for what medium?, in Young, D. ed. Language planning and medium in education: papers presented at the 5th annual conference of SAALA (Southern African Applied Linguistics Association), at the University of Cape Town, 9th to 11th October, 1986. Rondebosch, Cape Town: Language Education Unit and SAALA:1-11. 